\title{
Stanovisko výboru České společnosti pro aterosklerózu k doporučením ESC/EAS pro diagnostiku a léčbu dyslipidemií z roku 2019
}

(A statement of the Committee of the Czech Society for Atherosclerosis on the 2019 ESC/EAS guidelines for the diagnosis and treatment of dyslipidemia)

\section{Michal Vrablík ${ }^{a}$, Jan Pithaa, ${ }^{b, c}$, Vladimír Bláhad, Renata Cífkováe, Tomáš Freiberger ${ }^{f}, D^{2}$ avid Karásek ${ }^{g}$, Pavel Kraml$^{\mathrm{h}}$, Hana Rosolovách, Vladimír Soška ${ }^{\mathrm{i}, \mathrm{j}}$, Tomáš Štulca , Zuzana Urbanovák}

a III. interní klinika, 1. lékařská fakulta Univerzity Karlovy a Všeobecná fakultní nemocnice v Praze

b Interní klinika, 2. lékařská fakulta Univerzity Karlovy a Fakultní nemocnice v Motole, Praha

'Laboratoř pro výzkum aterosklerózy, Institut klinické a experimentální medicíny, Praha

d III. interní gerontometabolická klinika, Lékařská fakulta Univerzity Karlovy a Fakultní nemocnice Hradec Králové

e Centrum kardiovaskulární prevence, 1. lékařská fakulta Univerzity Karlovy a Thomayerova nemocnice, Praha

${ }^{f}$ Centrum kardiovaskulární a transplantační chirurgie Brno

${ }^{g}$ III. interní klinika - nefrologická, revmatologická a endokrinologická, Lékařská fakulta Univerzity Palackého a Fakultní nemocnice Olomouc

h II. interní klinika, 3. lékařská fakulta Univerzity Karlovy a Fakultní nemocnice Královské Vinohrady, Praha

ch II. interní klinika, Lékařská fakulta Univerzity Karlovy a Fakultní nemocnice Plzeň

iOddělení klinické biochemie, Fakultní nemocnice u sv. Anny v Brně

j II. interní klinika, Lékařská fakulta Masarykovy univerzity a Fakultní nemocnice u sv. Anny v Brně

${ }^{k}$ Klinika dětského a dorostového lékařství, 1. lékařská fakulta Univerzity Karlovy a Všeobecná fakultní nemocnice v Praze

INFORMACE O ČLÁNKU

Historie článku:

Vložen do systému: 8. 4. 2020

Prijat: 9. 4. 2020

Dostupný online: 20. 4. 2020

\section{Úvod}

V srpnu roku 2019 byla publikována nová verze doporučených postupů k diagnostice a léčbě dyslipidemií (DLP) autorů zastupujících Evropskou kardiologickou společnost (ESC) a Evropskou společnost pro aterosklerózu (EAS). ${ }^{1}$ Opět jde o komplexní a rozsáhlý materiál, který Ize považovat za referenční - reviduje důkazy, o které opíráme diagnostické a léčebné postupy, ale s ohledem na rozsah a komplexnost materiálu jej pravděpodobně nebudeme používat v denní praxi.

Výbor České společnosti pro aterosklerózu (ČSAT) zpracoval následující stanovisko jako souhrn nejdůležitějších a významných změn, které uvedený dokument odlišují od předcházejících guidelines ESC/EAS z roku 2016 a od stanoviska ČSAT $\mathrm{k}$ těmto doporučeným postupům publikovaného $v$ roce 2017.2,3 Výbor ČSAT považuje doporučení ESC/EAS 2019 pro léčbu dyslipidemií za vhodná i pro zdravotní péči v České republice.

Stanovisko nenahrazuje komentovaná doporučení a zájemcům o detailní znění doporučujeme k prostudování pưvodní kompletní text. Při srovnání současného a předchozího stanoviska ČSAT z roku 2017 zůstávají obecná pravidla hodnocení důkazů pro doporučení jednotlivých intervencí i použité formulace, které z nich vyplývají (je doporučeno, má být zváženo, mưže být za určitých okolností zváženo, není doporučeno); současné stanovisko však komentuje důležité změny, zahrnující i tabulkové shrnutí novinek.

Adresa pro korespondenci: Prof. MUDr. Michal Vrablík, Ph.D., III. interní klinika, 1. lékařská fakulta Univerzity Karlovy a Všeobecná fakultní nemocnice v Praze, U Nemocnice 504/1, 12808 Praha 2, e-mail: vrablíkm@seznam.cz

(C) 2020, ČKS

DOI: $10.33678 /$ cor.2020.024 


\section{Stanovení kardiovaskulárního rizika}

Pro stanovení kardiovaskulárního (KV) rizika se v nových guidelines objevují tabulky SCORE extendované do věku 70 let a omezené výší celkového cholesterolu použitého při výpočtu na $7 \mathrm{mmol} / \mathrm{l}$. Osoby s koncentrací celkového cholesterolu $8 \mathrm{mmol} / \mathrm{l}$ a vyšší (LDL-cholesterolu [LDL-C] 5 $\mathrm{mmol} / \mathrm{l}$ a vyšší) musejí být považovány za možné nositele familiární hypercholesterolemie, kteří jsou automaticky klasifikováni jako vysoce rizikoví. Pro Českou republiku jsou doporučeny tabulky pro vysoce rizikové populace (obr. 1). V brzké době se dočkáme národně specifických

\begin{tabular}{|c|c|}
\hline $\begin{array}{l}\text { Velmi } \\
\text { vysoké } \\
\text { riziko }\end{array}$ & $\begin{array}{l}\text { - Klinicky anebo zobrazovací metodou } \\
\text { prokázané KVO aterosklerotické etiologie } \\
\text { (ASKV). ASKVO zahrnuje předchozí } \\
\text { AKS (IM nebo nestabilní AP), stabilní AP, } \\
\text { koronární revaskularizace (PCI, CABG } \\
\text { a jiné arteriální revaskularizace), CMP } \\
\text { a TIA a ICHDK. Za ASKVO jednoznačně } \\
\text { prokázané zobrazovací metodou považujeme } \\
\text { nález nemoci více koronárních tepen se } \\
\text { stenózou dvou velkých epikardiálních tepen } \\
\text { >50\%) nebo významné AS změny karotid } \\
\text { detekované ultrazvukově } \\
\text { DM s orgánovým postižením anebo } \\
\text { př́tomnost nejméně tř́ velkých RF. Časně } \\
\text { vzniklý DM } 1 . \text { typu s dobou trvání > } 20 \text { let } \\
\text { CKD } 4 \text {. a } 5 \text {. stupně (eGFR < } 30 \text { ml/min } 1,73 \text { m²) } \\
\text { Vypočtené riziko fatální KV příhody pomo- } \\
\text { cí SCORE } \geq 10 \% \\
\text { FH s ASKVO nebo alespoň jedním dalším } \\
\text { významným rizikovým faktorem }\end{array}$ \\
\hline Vysok & $\begin{array}{l}\text { - Významné zvýšení izolovaného rizikového } \\
\text { faktoru, zejména TC }>8 \mathrm{mmol} / /, \mathrm{LDL}-\mathrm{C} \\
>4,9 \mathrm{mmol} / \mathrm{l} \text { nebo TK } \geq 180 / 110 \mathrm{~mm} \mathrm{Hg} \\
\text { - Pacienti } \mathrm{s} \text { FH bez dalších významných } \\
\text { rizikových faktorů } \\
\text { - Pacienti s DM bez orgánového poškození, } \\
\text { s dobou trvání DM } \geq 10 \text { let nebo s dalším } \\
\text { rizikovým faktorem } \\
\text { - CKD } 2 \text { a } 3 \text {. stupně (eGFR } 30-59 \mathrm{l} / \mathrm{min} / 1,73 \mathrm{~m}^{2} \text { ) } \\
\text { - Vypočtené riziko fatální } \mathrm{KV} \text { príhody pomo- } \\
\text { cí SCORE } \geq 5 \% \text { a }<10 \%\end{array}$ \\
\hline Střední riziko & $\begin{array}{l}\text { - Mladí pacienti (s DM 1. typu do } 35 \text { let } \\
\text { věku; DM 2. typu do } 50 \text { let věku) s trváním } \\
\text { diabetu }<10 \text { let, bez dalších rizikových } \\
\text { faktorů } \\
\text { - Vypočtené riziko fatální KV príhody } \\
\text { pomocí SCORE } \geq 1 \% \text { a }<5 \%\end{array}$ \\
\hline Nízké riziko & $\begin{array}{l}\text { - Vypočtené riziko fatální KV přihody } \\
\text { pomocí SCORE }<1 \%\end{array}$ \\
\hline
\end{tabular}

AKS - akutní koronární syndrom; ASKVO - aterosklerotické kardiovaskulární onemocnění; CABG (coronary artery bypass graft) - aortokoronární bypass; CKD (chronic kidney disease) - chronické onemocnění ledvin; CT - výpočetní tomografie; DM - diabetes mellitus; eGFR (estimated glomerular filtration rate) - odhadovaná glomerulární filtrace; FH - familiární hypercholesterolemie; IM - infarkt myokardu; KVO - kardiovaskulární onemocnění; LDL-C (low-density lipoprotein cholesterol) - cholesterol v lipoproteinech o nízké hustotě; $\mathrm{PCl}$ - perkutánní koronární intervence; RF - rizikový faktor; SCORE - Systematic Coronary Risk Estimation; TC - celkový cholesterol; TIA - tranzitorní ischemická ataka; TK - krevní tlak. tabulek pro Česko. Výhodné je použití elektronické verze SCORE dostupné na www.heartscore.org.

Nová doporučení se vracejí k hodnocení stavů spojených s velmi vysokým cévním rizikem na základě zobrazovacích metod. Zdůrazňují roli vyšetření kalciového skóre koronárních tepen (CAC), které má být zváženo (při dobré dostupnosti) ke zpřesnění rizika u osob ve střední rizikové kategorii. Podobně Ize použít vyšetření karotických nebo femorálních tepen pomocí duplexního ultrazvukového vyšetření. Jednoznačný nález aterosklerotického plátu je důvodem $\mathrm{k}$ reklasifikaci nemocného do úrovně velmi vysokého rizika. Tabulka 1 uvádí rozdělení kategorií KV rizika s výčtem jednotlivých klinických situací rozhodných pro kategorizaci pacienta. Nově se $v$ textu guidelines objevuje kategorie nemocných s rekurentní aterotrombotickou př́hodou do dvou let po první události při zavedené léčbě. Tito nemocní mají být považováni za extrémně rizikové a vyžadují maximální intenzitu intervence.

Důležité je připomenout, že riziko zvyšují další modifikující faktory (sociální deprivace, psychiatrické komorbidity, hypertrofie levé komory srdeční, nealkoholová jaterní steatóza, fibrilace síní a další, viz rámeček 4 originálního dokumentu). Tyto modifikátory rizika nabývají na důležitosti zejména u osob ve střední rizikové kategorii, kdy mohou usnadnit rozhodování o volbě hypolipidemické strategie.

K otázce vlivu HDL-cholesterolu (HDL-C) na modifikaci celkového rizika aterosklerotického kardiovaskulárního onemocnění (ASKVO) přispěly nové epidemiologické i genetické studie. Nadále platí, že nízká koncentrace HDL-C významně zvyšuje KV riziko. Doporučení ESC/EAS 2019 poprvé uvádějí, že koncentrace HDL-C > 2,1 mmol/l u mužů a > 2,3 mmol/l u žen nejsou spojeny s redukcí rizi$k a$, a mohou jej dokonce zvyšovat.

Ostatní zásady posuzování KV rizika se nemění ani nejsou považovány za kontroverzní. U mladších osob se doporučuje tabulka relativního rizika nebo stanovení tzv. vaskulárního věku (srovnání věku vyšetřovaného s věkem osoby se stejným vypočteným rizikem dle SCORE při optimální konstelaci rizikových faktorů). V českých podmínkách využíváme národně specifické tabulky konstruované na základě epidemiologických dat z národních sledování.

\section{Laboratorní vyšetření lipidů a lipoproteinů}

Doporučení nově vyzdvihují roli apolipoproteinu B (apoB) při hodnocení rizika ASKVO (tabulka 2). Stanovení koncentrace apoB je doporučeno preferovat zejména u osob s velmi nízkou koncentrací LDL-C, hypertriglyceridemií, diabetem či metabolickým syndromem. ApoB může být použit pro diagnostiku, screening i v rámci léčby pacientů s DLP jako alternativa LDL-C. V uvedených situacích riziko ASKVO reflektuje i non-HDL-cholesterol, jehož vyšetření není spojeno s dodatečnými náklady.

Poprvé se v doporučených postupech objevuje „povinné" vyšetření koncentrace lipoproteinu(a) u všech osob alespoň jedenkrát v životě. Pacienti s koncentracemi Lp(a) $>180 \mathrm{mg} / \mathrm{dl}(430 \mathrm{nmol} / \mathrm{l})$ mají celoživotní riziko shodné s nemocnými s familiární hypercholesterolemií. Zjištění vysoké koncentrace Lp(a) může sloužit ke změně kategorie rizika. 


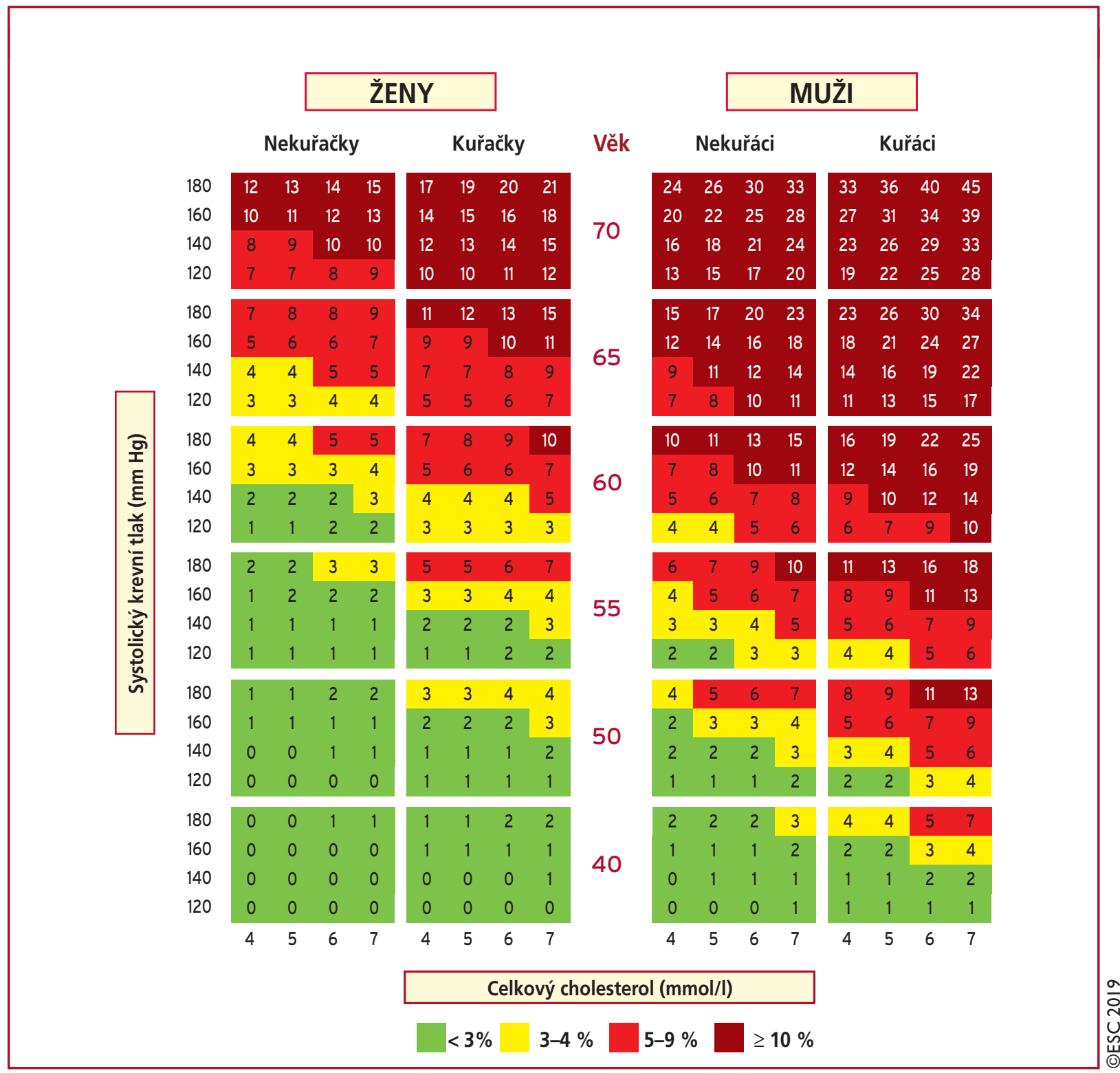

Obr. 1 - Tabulka SCORE pro výpočet kardiovaskulárního rizika (desetiletého rizika fatálního KVO) pro regiony s vysokým KV rizikem v Evropě. Upraveno podle ${ }^{1}$. KVO - kardiovaskulární onemocnění.

Tabulka 2 - Změny v doporučeních pro vyšetření koncentrací lipidů a lipoproteinů v séru

- Koncentrace apolipoproteinu B může být použita jako primární parametr pro screening, diagnostiku a léčbu nemocných s DLP místo LDL-C.

- Koncentracea Lp(a) má být vyšetřena minimálně jedenkrát $v$ životě k identifikaci osob s velmi vysokými hodnotami (> 180 $\mathrm{mg} / \mathrm{dl}$ nebo $430 \mathrm{nmol} / \mathrm{l})$, jejichž riziko je ekvivalentní riziku pacientů s familiární hypercholesterolemií.

- Stanovení koncentrací lipidů a lipoproteinů ve vzorcích krve odebraných bez předchozího lačnění nepovažujeme nadále v našich podmínkách za vhodné, ale mưže být použito v rámci screeningových aktivit s dostatečnou přesností.
Další obecná doporučení o vyšetřování krevních lipidů a lipoproteinů zůstávají nezměněna. Pro určení míry kardiovaskulárního rizika pomocí SCORE zůstává hlavním parametrem koncentrace celkového cholesterolu. LDL-cholesterol je nadále hlavním léčebným cílem, determinantem rizikovosti i screeningovým parametrem; může být nahrazen koncentrací apolipoproteinu B. Zejména nízká koncentrace HDL-cholesterolu modifikuje dále riziko a má být vyšetřena v rámci screeningu i před zahájením léčby. Navíc zjištění HDL-cholesterolemie potřebujeme pro určení koncentrace non-HDL-cholesterolu, indikované ve stejných situacích jako hodnocení apoB. 
Tabulka 3 - Cílové hodnoty LDL-C, non-HDL-C a apolipoproteinu B

\begin{tabular}{|l|l|l|l|l|l|}
\hline Riziko & Nízké & Středně zvýšené & Vysoké & Velmi vysoké & Extrémní \\
\hline LDL-C $(\mathrm{mmol} / \mathrm{l})$ & $<3,0$ & $<2,6$ a snížení o nejméně & $<1,8$ a snížení o nejméně & $<1,4$ a snížení o nejméně \\
\hline & & $50 \%$ hodnot před léčbou & $50 \%$ hodnot před léčbou & $50 \%$ hodnot před léčbou \\
\hline Non-HDL-C $(\mathrm{mmol} / \mathrm{l})$ & $<3,8$ & $<3,4$ & $<2,6$ & $<2,2$ \\
\hline apoB $(\mathrm{g} / \mathrm{l})$ & - & $<1$ & $<0,8$ & $<0,65$
\end{tabular}

apoB - apolipoprotein B; LDL-C - LDL-cholesterol; non-HDL-C - non-HDL-cholesterol.

\section{Cílové hodnoty lipidů a lipoproteinů}

Základním léčebným cílem zưstává i v poslední verzi doporučených postupů LDL-cholesterol (LDL-C), sekundárními léčebnými cíli jsou koncentrace apoB a non-HDL-C. $S$ ohledem na kumulaci nových dokladů z intervenčních studií se opět významně posunují doporučené cílové hodnoty ve všech rizikových kategoriích kromě osob s nízkým rizikem, které zůstávají beze změn. Jejich přehled uvádí tabulka 3.

Nově doporučení postulují požadavek nejen na dosažení určité cílové koncentrace LDL-C, ale také potřebu minimálně $50 \%$ snížení ve srovnání s koncentrací před léčbou. Další snížení cílových hodnot zohledňuje skutečnost, že všechny dosavadní intervenční studie zaměřené na snižování LDL-C ukázaly přímý vztah mezi dosaženou koncentrací LDL-C a poklesem cévního rizika bez ohledu na vstupní koncentraci LDL-C (tedy princip „čím níže, tím lépe"). Snížení cílových hodnot vždy vyvolává diskuse, a proto považujeme za účelné shrnout nejdůležitější důkazy shromážděné od publikace předchozí verze doporučených postupů, které představují základní „důkazní materiál“ podporující nové cíle léčby (tabulka 4).

Sekundárním cílem zejména u osob s hypertriglyceridemií je non-HDL-cholesterol, jehož cílová hodnota je o 0,8 mmol/l vyšší než doporučený cíl pro LDL-C v dané rizikové kategorii. Podobně používáme i sledování hodnoty apoB, jehož koncentrace u velmi vysoce rizikových osob má být snížena na hodnotu nižší než 0,65 g/l, v kategorii vysokého rizika na hodnotu nižší než 0,8 g/l a u osob se středně zvýšeným rizikem na hodnotu nižší než 1,0 g/l. Koncentrace triglyceridů $(\mathrm{TG})>1,7 \mathrm{mmol} / \mathrm{l}$ a koncentrace $\mathrm{HDL}-\mathrm{C}<1,0 \mathrm{mmol} / \mathrm{l}$ u mužů a $<1,2 \mathrm{mmol} / \mathrm{l}$ u žen jsou sice

\begin{tabular}{|c|c|c|}
\hline \multirow{2}{*}{$\begin{array}{l}\text { Kategorie } \\
\text { rizika }\end{array}$} & \multicolumn{2}{|l|}{ Cílová hodnota LDL-C } \\
\hline & 2016 & 2019 \\
\hline $\begin{array}{l}\text { Velmi vysoké } \\
\text { riziko }\end{array}$ & $\begin{array}{l}<1,8 \mathrm{mmol} / \mathrm{l} \text { nebo } \\
>50 \% \downarrow \text {, když je } \\
\text { LDL-C } 1,8-3,5 \mathrm{mmol} / \mathrm{l}\end{array}$ & $\begin{array}{l}<1,4 \mathrm{mmol} / / \\
a>50 \% \downarrow\end{array}$ \\
\hline Vysoké riziko & $\begin{array}{l}<2,6 \mathrm{mmol} / / \text { nebo } \\
>50 \% \downarrow, \mathrm{když} \mathrm{je} \\
\text { LDL-C } 2,6-5,2 \mathrm{mmol} / \mathrm{l}\end{array}$ & $\begin{array}{l}<1,8 \mathrm{mmol} / \mathrm{l} \\
a>50 \% \downarrow\end{array}$ \\
\hline Střední riziko & $<3,0 \mathrm{mmol} / \mathrm{l}$ & $<2,6 \mathrm{mmol} / \mathrm{l}$ \\
\hline Nízké riziko & $<3,0 \mathrm{mmol} / \mathrm{l}$ & $<3,0 \mathrm{mmol} / \mathrm{l}$ \\
\hline
\end{tabular}

LDL-C - LDL-cholesterol.

dále považovány za důležité modulátory rizika, ne však za léčebné cíle. Oba tyto parametry uspokojivě zohledňuje cílová hodnota non-HDL-cholesterolu či apolipoproteinu B.

Tabulka 5 shrnuje změny cílových hodnot oproti doporučeným postupům z roku 2016.

Navíc u nemocných s rekurentní aterotrombotickou príhodou do dvou let od první události při terapii maximální tolerovanou dávkou statinu a ezetimibem je doporučeno snížení LDL-C na hodnotu nižší než 1,0 mmol/l.

Všechny posuny cílových hodnot vyústí v nutnost používání intenzivní statinové terapie většinou v kombinaci s ezetimibem u širšího spektra nemocných. Nové cílové hodnoty bude $u$ některých pacientů možno dosahovat pouze při využití nových léčebných možností (např. inhibitory proprotein konvertázy subtilisin/kexin typu 9 [PCSK9]).

\section{Tabulka 4 - Přehled hlavních důkazů pro snižení cílové hodnoty LDL-C na 1,4 mmol/l v kategorii velmi vysokého KV rizika}

\begin{tabular}{|c|c|c|c|}
\hline Studie & $\begin{array}{l}\text { Dosažené koncentrace } \\
\text { LDL-C; placebo vs. } \\
\text { aktivní léčba (mmol/l) }\end{array}$ & Sledované ukazatele & $\begin{array}{l}\text { RR }(95 \% \mathrm{Cl}) \\
\text { (při snížení LDL-C } \\
\text { o } 1 \mathrm{mmol} / \mathrm{l})\end{array}$ \\
\hline $\begin{array}{l}\text { Metaanalýza } \mathrm{CTT}^{12} \text { (vysoce intenzivní léčba vs. standardní } \\
\text { léčba statinem; subpopulace }<2,0 \mathrm{mmol} / \mathrm{l})\end{array}$ & 1,71 vs. 1,32 & $\begin{array}{l}\text { IM, úmrtí z koronárních příčin, } \\
\text { CMP, koronární revaskularizace }\end{array}$ & $0,71(0,56-0,91)$ \\
\hline IMPROVE-IT ${ }^{13}$ (ezetimib + statin vs. statin) & 1,80 vs. 1,40 & $\begin{array}{l}\text { Úmrtí z KV přícin, IM, CMP, nestabilní } \\
\mathrm{AP} \text {, koronární revaskularizace }\end{array}$ & $0,94(0,89-0,99)$ \\
\hline $\begin{array}{l}\text { FOURIER }^{14} \text { (evolocumab plus vysoká dávka statinu } \pm \\
\text { ezetimib vs. vysoká dávka statinu } \pm \text { ezetimib) }\end{array}$ & 2,37 vs. 0,78 & $\begin{array}{l}\text { Úmrtí z KV př́ǐcin, IM, CMP, } \\
\text { nestabilní AP, koronární } \\
\text { revaskularizace }\end{array}$ & $0,85(0,79-0,92)$ \\
\hline $\begin{array}{l}\text { ODYSSEY OUTCOMES } 15 \text { (alirocumab plus vysoká dávka } \\
\text { statinu } \pm \text { ezetimib vs. vysoká dávka statinu } \pm \text { ezetimib) }\end{array}$ & 2,61 vs. 1,37 & $\begin{array}{l}\text { IM, úmrtí z koronárních příčin, } \\
\text { CMP, nestabilní AP }\end{array}$ & $0,85(0,78-0,93)$ \\
\hline
\end{tabular}

AP - angina pectoris; Cl - interval spolehlivosti; CMP - cévní mozková příhoda; IM - infarkt myokardu; KV - kardiovaskulární; RR - relativní riziko. 


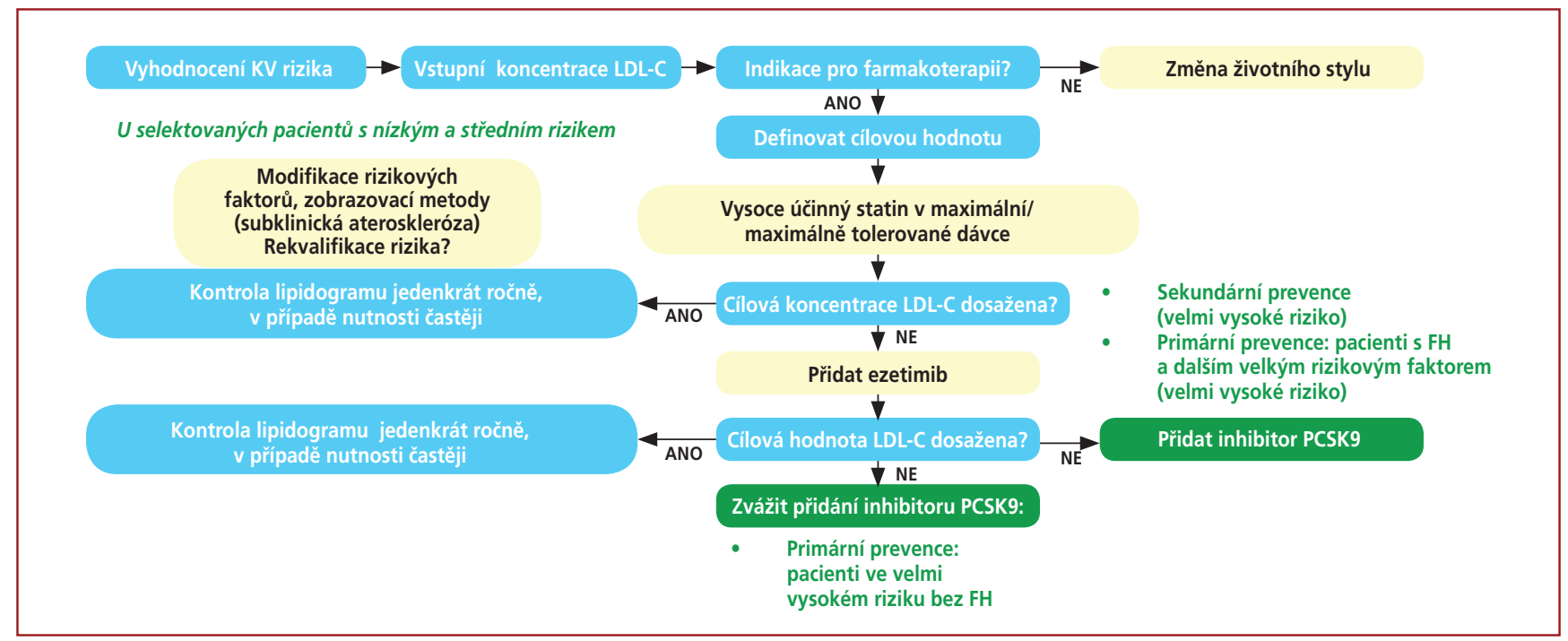

Obr. 2 - Terapeutický algoritmus pro snižování LDL-C. Upraveno podle 1 . FH - familiární hypercholesterolemie, LDL-C - cholesterol v lipoproteinech o nízké hustotě; PCSK9 - proprotein konvertáza subtilisin/kexin typu 9.

\section{Změny životního stylu v léčbě DLP (nefarmakologická opatření)}

V oddíle komentovaných doporučených postupů ESC/EAS věnovaném režimovým opatřením $v$ léčbě DLP nedošlo k zásadním změnám proti předchozí verzi. Nefarmakologická opatření nadále představují základ léčby dyslipidemie $\mathrm{i}$ intervence rizika ASKVO. Optimalizace tělesné hmotnosti, nekuřáctví, dostatečná pohybová aktivita jsou stále nejdủležitějšími požadavky. Doporučení ke změně diety mají vycházet z regionálních zvyklostí. Za nejdůležitější z hlediska snížení hodnot LDL-cholesterolu a celkového cholesterolu nadále považují autoři doporučených postupů eliminaci konzumace transmastných kyselin a snížení podílu nasycených tukủ na méně než 7 \% celkového energetického príijmu a jejich nahrazení nenasycenými tuky. Pro snížení triglyceridů je rozhodující redukce nadměrné tělesné hmotnosti a omezení konzumace alkoholu, pro zvýšení HDL-cholesterolu eliminace transmastných kyselin a zvýšení fyzické aktivity. Střídmá konzumace alkoholu definovaná jako spotřeba méně než $10 \mathrm{~g}$ alkoholu denně pro muže i ženy není doporučena, ale může být tolerována u osob, které již alkohol konzumují a nemají hypertriglyceridemii. Komentovaná doporučení ESC/EAS z roku 2019 rozebírají i otázku tzv. funkčních potravin neboli nutraceutik se zvláštním vlivem na hodnoty krevních lipoproteinů a možným př́źnivým efektem na lipidogram i riziko ASKVO (např. polikosanol, rostlinné steroly, $\omega-3$ mastné kyseliny, berberin, extrakt z červené fermentované rýže a další). Fytosteroly a extrakty z červené fermentované rýže obsahující monakolin $\mathrm{K}$ mohou být zváženy u osob nedosahujících cílové hodnoty LDL-C při režimových opatřeních za předpokladu, že se nekvalifikují pro farmakoterapii statinem.

\section{Farmakoterapie dyslipidemií}

Hlavní farmakoterapeutické postupy v léčbě DLP se nemění.

\section{Statiny}

Statiny nadále představují léčbu volby u osob se zvýšeným rizikem ASKVO a zvýšenou koncentrací LDL-C či dalších aterogenních lipoproteinů. Doporučené postupy zdưrazňují nutnost individualizace léčby, titrace dávky $k$ dosažení léčebných cílů a vhodnost kombinace, není-li možné maximální tolerovanou dávkou statinu cílových hodnot dosáhnout.

\section{Sekvestranty žlučových kyselin (pryskyřice)}

Sekvestranty žlučových kyselin (pryskyřice) své místo v doporučených postupech mají nadále, přestože v klinické praxi v našich podmínkách se s nimi setkáváme velmi omezeně. Hlavní limit použití představuje gastrointestinální intolerance. Pryskyřice mají však nadále své místo v léčbě zejména u osob se statinovou intolerancí či pacientů nedosahujících cílových hodnot LDL-C při další léčbě, případně u žen $\mathrm{s}$ familiární hypercholesterolemií v období těhotenství a laktace. Nejvýhodnější (a nejlépe tolerované) jsou vysoce polymerní pryskyřice (colesevelam), v ČR je aktuálně dostupný pouze cholestyramin.

\section{Inhibitory vstřebávání cholesterolu}

Inhibitory vstřebávání cholesterolu reprezentované nadále jediným zástupcem této tř́́dy ezetimibem se od vydání předchozí verze doporučených postupů dočkaly dalších dokladů opravňujících novou formulaci doporučení k jeho použití. Nově guidelines uvádějí, že ezetimib je doporučen do kombinace u pacientů nedosahujících cílové hodnoty LDL-C při maximální/maximálně tolerované dávce statinu. Doporučení rekapitulují příznivý bezpečnostní profil, jednoduchost léčby (uniformní dávkování, nezávislost na denní době či př́ijmu potravy), navíc v poslední době podpořenou dostupností fixních kombinací se statiny.

\section{Inhibitory proprotein konvertázy subtilisin/kexin typu 9 (PCSK9i)}

Inhibitory proprotein konvertázy subtilisin/kexin typu 9 (PCSK9i), monoklonální protilátky specificky blokující 
interakci tohoto proteinu s LDL-receptorem, dostávají v guidelines verze 2019 vyšší úroveň doporučení. Alirocumab a evolocumab mají být zváženy v situacích, kdy nelze dosáhnout stanovených cílových hodnot při použití maximálně tolerované dávky statinu v kombinaci s ezetimibem. Použití v klinické praxi v Česku se řídí nejenom doporučeními odborných společností, ale významně jej ovlivňují i podmínky úhrady stanovené Státním ústavem pro kontrolu léčiv. V detailu odkazujeme na publikované dokumenty $\mathrm{k}$ tomuto tématu. .,5 $^{4}$

V dalším textu uvedeme v přehledu s využitím tabulek z textu doporučení ESC/EAS k léčbě DLP z roku 2019 hlavní principy farmakologických možností ovlivnění jednotlivých poruch metabolismu lipidů a lipoproteinů v séru.

\section{Farmakoterapie hypercholesterolemie}

Základní volby farmakologické léčby k ovlivnění hypercholesterolemie zůstávají neměnné. Účinné statiny titrované $\mathrm{k}$ dosažení cílové hodnoty LDL-C představují základní stupeň farmakoterapie, k níž přidáváme ezetimib prípadně inhibitor PCSK9. Algoritmus snižování LDL-C uvádí obrázek 2.

\section{Farmakoterapie hypertriglyceridemie}

Nadále rozlišujeme dvě hlavní klinické indikace ke snižování koncentrací triglyceridů. U významné hypertriglyceridemie s koncentracemi TG > $10 \mathrm{mmol} / \mathrm{l}$ je třeba snížením hodnot omezit riziko akutní pankreatitidy. Přes nesporně zásadní roli nefarmakologického přístupu při léčbě této dyslipidemie je léčivem první volby v této situaci fenofibrát, prípadně v kombinaci s vysokými dávkami (3-4 g denně) $\omega-3$ mastných kyselin. Ty se nově objevují v doporučeních pro léčbu hypertriglyceridemie u (velmi) vysoce rizikových, protože derivát kyseliny eikosapentaenové (ikosapent etyl) v dávce $4 \mathrm{~g}$ denně ve studii REDUCE-IT přinesl další významné snížení rizika právě u takových pacientů.

\begin{tabular}{|c|c|c|}
\hline Doporučení & $\begin{array}{c}\text { Tř́da } \\
\text { doporučení }\end{array}$ & $\begin{array}{l}\text { Úroveň } \\
\text { důkazů }\end{array}$ \\
\hline $\begin{array}{l}\text { U vysoce rizikových nemocných } \\
\text { s hypertriglyceridemií > 2,3 mmol// Ize } \\
\text { jako lék první volby ke snížení rizika } \\
\text { ASKVO zvolit statin. }\end{array}$ & I & B \\
\hline $\begin{array}{l}\text { U vysoce a velmi vysoce rizikových } \\
\text { nemocných s TG 1,5-5,6 mmol/l i při } \\
\text { léčbě statiny by mělo být zváženo } \\
\text { přidání } \omega-3 \text { mastných kyselin } \\
\text { (ikosapent ethyl } 2 \times 2 \mathrm{~g} \text { denně). }\end{array}$ & Ila & B \\
\hline $\begin{array}{l}\text { U osob s trvající hodnotou TG > 2,3 } \\
\text { mmol// při dosažení cílové hodnoty } \\
\text { LDL-C mǔže být zváženo přidání } \\
\text { fenofibrátu k zavedené terapii } \\
\text { statinem. }\end{array}$ & Ilb & C \\
\hline
\end{tabular}

ASKVO - aterosklerotické kardiovaskulární onemocnění; LDL-C LDL-cholesterol; TG - triglyceridy.

Farmakologická léčba mírně a středně zvýšených koncentrací triglyceridů do $10 \mathrm{mmol} / \mathrm{l}$ má být zvážena v kontextu vysokého a velmi vysokého rizika. Lékem volby jsou statiny. V prípadě trvajícího zvýšení koncentrací triglyceridů nad hodnoty 2,3 $\mathrm{mmol} / /$ Ize zvážit jejich kombinaci s fenofibrátem (tabulka 6).

$\mathrm{Na}$ rozdíl od verze doporučených postupů ESC/EAS 2016 nenajdeme v těch aktuálních specifický odstavec o léčbě zaměřené na zvyšování koncentrací HDL-C. Randomizované studie s inhibitory CETP (cholesterol-ester transfer protein, které zvyšují koncentrace HDL-C až dvojnásobně) nepřinesly očekávané přídatné snížení rizika ASKVO a nebudou uvedeny do klinického použití. Další úrovně důkazů z epidemiologických a mendeliánských randomizačních studií rovněž nepodporují koncept zvyšování HDL-C jako směr k další redukci rizika ASKVO.

\section{Léčba DLP ve specifických skupinách pacientů}

Oddíl doporučených postupů ESC/EAS věnovaný vyjmenovaným populačním skupinám se zásadně nezměnil. Přibyly některé důkazy pro určité subpopulace, které umožnily posun trrídy doporučení. Pro přehlednost a stručnost uvedeme $v$ tomto stanovisku pouze tabelovaná shrnutí k jednotlivým pacientským skupinám se zaměřením na odlišnosti od poslední verze doporučení z roku 2016.

\section{Familiární dyslipidemie}

Tabulka 7 - Doporučení pro vyhledávání a léčbu pacientů s heterozygotní formou familiární hypercholesterolemie (FH)

Doporučení

Na FH bychom měli myslet u pacientů s ICHS vzniklou u mužů mladších 55 let a žen mladších 60 let, u osob, u jejichž príbuzných se KVO manifestovalo předčasně nebo u jejichž príbuzných se objevily šlachové xantomy, a u osob $s$ velmi zvýšeným LDL-C (u dospělých > $5 \mathrm{mmol} / \mathrm{l}$, u dětí $>4 \mathrm{mmol} / \mathrm{l})$.

Je doporučeno potvrdit diagnózu FH klinickými kritérii, a pokud je to možné, také DNA diagnostikou.

Pokud je diagnostikován první př́pad v rodině, je doporučen kaskádový rodinný screening.

Je doporučeno, aby pacienti s FH a dokumentovaným ASKVO nebo ti s alespoň jedním dalším velkým rizikovým faktorem byli léčeni jako velmi vysoce rizikoví a ostatní jako vysoce rizikoví.

Cílovými hodnotami pro léčbu nemocných $\mathrm{s} F \mathrm{H}$ ve velmi vysokém riziku je $\mathrm{LDL}-\mathrm{C}<1,4 \mathrm{mmol} / \mathrm{l}$ a současně snížení koncentrace LDL-C o nejméně $50 \%$. Pokud není možno dosáhnout cílových hodnot, je třeba snažit se o maximální snížení LDL-C pomocí vhodných lékových kombinací.

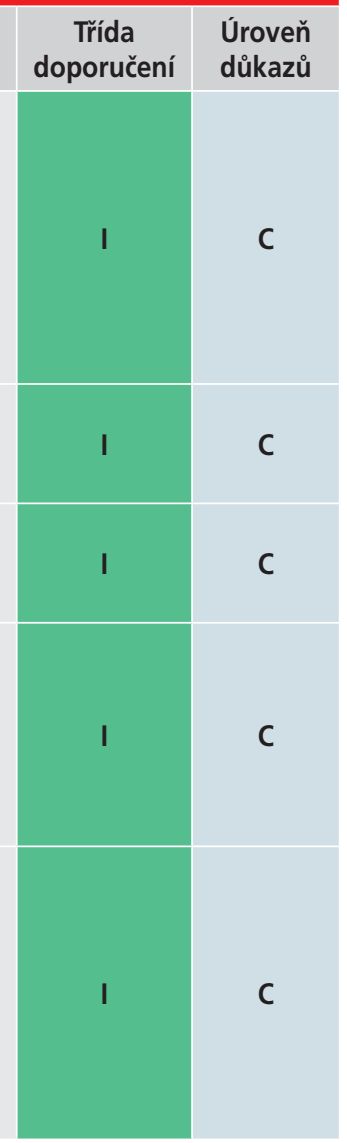


Tabulka 7 - Doporučení pro vyhledávání a léčbu pacientů

s heterozygotni formou familiární hypercholesterolemie (FH) (dokončeni)

Léčba pomocí inhibitorů PCSK9 je doporučena u velmi vysoce rizikových pacientů s $\mathrm{FH}$, u nichž léčba maximální tolerovanou dávkou statinu s ezetimibem nevedla $k$ dosažení cílové hodnoty LDL-C.

U dětí je doporučeno vyšetřování od pěti let věku nebo při suspektní homozygotní formě $\mathrm{FH}$ i dříve.

Děti s FH by měly být podrobně poučeny o nutnosti dodržovat vhodnou dietu a léčeny statiny od věku 8-10 let. Cílovými hodnotami pro léčbu dětí ve věku nad 10 let je LDL-C $<3,5 \mathrm{mmol} / \mathrm{l}$.

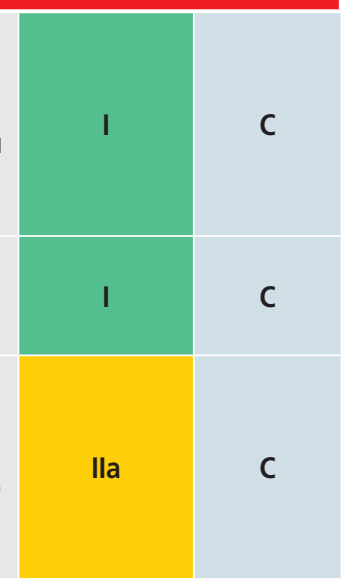

ASKVO - aterosklerotické kardiovaskulární onemocnění; ICHS ischemická choroba srdeční; FH - familiární hypercholesterolemie; KVO - kardiovaskulární onemocnění; LDL-C - LDL-cholesterol.

Tento oddíl doporučených postupů pojednává o nejčastějších dobře definovaných formách familiárních dyslipidemií. Největší prostor se dostává familiární hypercholesterolemii, jejíž diagnostiku a vedení léčby shrnuje tabulka 7.

Diagnostice a léčbě pacientů s familiární hypercholesterolemií se věnují samostatné dokumenty pro dospělé i dětské pacienty s FH vypracované ČSAT. ${ }^{7,8}$ Familiární hypercholesterolemie představuje také jedinou situaci, kdy $v$ dětském věku rutinně indikujeme hypolipidemickou farmakoterapii. Ta by vždy měla být vedena zkušeným specialistou, v České republice je možné využít sít pediatrických pracovišt' projektu MedPed (seznam na www.athero. Cz). Centra projektu MedPed slouží i ke konzultacím diagnostiky a léčby pacientů s familiárními dyslipidemiemi.

\section{Ženská populace}

Pro léčbu DLP u žen platí stejná pravidla jako u mužů. Doporučené postupy nadále podporují stejné principy léčby u žen jako u mužů, přestože zejména ve starších studiích nebylo zastoupení ženského pohlaví vždy dostatečné. Výsledky klinických hodnocení ale vyznívají jednoznačně a prínos hypolipidemických intervencí u žen považujeme

Tabulka 8 - Léčba dyslipidemie u žen
Doporučení
- V primární prevenci ASKVO je u žen s vysokým rizikem
doporučena léčba statiny.
- V sekundární prevenci ASKVO jsou u žen doporučeny stejné
indikace a cílové hodnoty jako u mužů.
- Hypolipidemika by neměla být podávána ženám plánujíím
těhotenství, během těhotenství a během kojení. U pacientů
s těžkou FH Ize však zvážit podávání sekvestrantů žlučových
kyselin, které se nevstřebávají z trávicího ústrojí nebo LDL-aferézu.

ASKVO - aterosklerotické kardiovaskulární onemocnění; $\mathrm{FH}$ - familiární hypercholesterolemie. za prokázaný. Je možné a pravděpodobné, že v další verzi doporučených postupů nebude populace žen vyjmenována mezi specifickými subpopulacemi; nesprávná interpretace nižšího rizika ASKVO u žen do věku asi 55-60 let jako známky "celoživotní ochrany" snad z praxe již nyní mizí (tabulka 8).

\section{Pacienti vyššího věku}

Guidelines ESC/EAS 2019 definuji tuto skupinu věkem nad 65 let. Od publikace přechozích doporučení máme $\mathrm{k}$ dispozici některé nové epidemiologické studie i souhrnné metaanalýzy sledující nemocné vyššího věku. Připomeňme, že více než 80 \% zemřelých na ASKVO je ve věkové kategorii starších 65 let. V souvislosti s prodlužující se délkou života se významně zvyšuje počet osob s infarktem myokardu (IM) starších 85 let. Konečně absolutní riziko pacientů vyššího věku je větší, a proto léčba přináší větší absolutní přínos. Z těchto důvodů nacházíme v guidelines jednoznačnější doporučení k vedení hypolipidemické terapie v nejvyšších třídách (tabulka 9).

Tabulka 9 - Doporučení pro léčbu dyslipidemifi u osob starších 65 let

\begin{tabular}{|c|c|c|}
\hline Doporučení & $\begin{array}{c}\text { Tř́da } \\
\text { doporučení }\end{array}$ & $\begin{array}{l}\text { Úroveň } \\
\text { důkazů }\end{array}$ \\
\hline $\begin{array}{l}\text { Léčba statiny je u starších nemocných } \\
\text { se známým ASKVO doporučena stejně } \\
\text { jako u mladších pacientů. }\end{array}$ & I & A \\
\hline $\begin{array}{l}\text { Je doporučeno, aby léčba statiny byla } \\
\text { zahajována nízkou dávkou u osob } \\
\text { s poklesem renálních funkcí nebo } \\
\text { v případě možných lékových interakcí. } \\
\text { Léćba má být titrována k dosažení } \\
\text { cílových hodnot LDL-C podle stejných } \\
\text { principủ jako u mladších osob. }\end{array}$ & I & A \\
\hline $\begin{array}{l}\text { Léčba statiny je indikována u osob } \\
\text { v primární prevenci podle kategorie } \\
\text { rizika u osob mladších } 75 \text { let. }\end{array}$ & Ilb & B \\
\hline $\begin{array}{l}\text { Léčbu statiny je možné zvážit u osob } \\
\text { v primární prevenci, u osob starších } \\
75 \text { let v kontextu vysokého nebo velmi } \\
\text { vysokého KV rizika. }\end{array}$ & I & C \\
\hline
\end{tabular}

ASKVO - aterosklerotické kardiovaskulární onemocnění; KV - kardiovaskulární; LDL-C - LDL-cholesterol.

\section{Pacienti s diabetes mellitus}

Diabetici 1. i 2. typu mají zvýšené riziko ASKVO. I proto je farmakologická léčba DLP zpravidla nezbytná. Její principy se nemění a jsou shrnuty v tabulce 10 .

Aktuální verze guidelines zdůrazňuje specifika dyslipidemie vznikající $v$ kontextu inzulinové rezistence (zmnožení remnantních na triglyceridy bohatých a vysoce aterogenních lipoproteinových částic, snížení koncentrací HDL-C, změny postprandiálního metabolismu lipoproteinů). Proto je DLP provázející diabetes, prediabetes a metabolický syndrom zvláště významným faktorem negativně ovlivňujícím riziko ASKVO. I u diabetiků 1. typu se zvyšuje prevalence metabolického syndromu 
Tabulka 10 - Doporučení pro léčbu dyslipidemie u diabetes mellitus (DM)

\section{Doporučení}

U pacientů s DM 2. typu ve velmi vysokém riziku je doporučeno snížení koncentrace LDL-C nejméně o $50 \%$ a současně dosažení cílové hodnoty $\mathrm{LDL}-\mathrm{C}<1,4 \mathrm{mmol} / \mathrm{l}$.

U pacientů s DM 2. typu ve vysokém riziku je doporučeno snižení koncentrace LDL-C nejméně o $50 \%$ a současně dosažení cílové hodnoty $\mathrm{LDL}-\mathrm{C}<1,8 \mathrm{mmol} / \mathrm{l}$.

Statiny jsou doporučeny u pacientů s DM 1. typu ve vysokém nebo velmi vysokém riziku.

Před zahájením kombinačních hypolipidemických režimů je doporučeno intenzifikovat terapii statinem.

Není-li dosaženo cílové koncentrace LDL-C, měla by být zvážena kombinace statinu s ezetimibem.

Terapie statinem může být zvážena u pacientů s diabetem 1. i 2. typu starších 30 let se známkami orgánového postižení a koncentracemi LDL-C $>2,5$ $\mathrm{mmol} / \mathrm{l}$ za předpokladu, že není plánována gravidita.

DM - diabetes melitus; LDL-C - LDL-cholesterol.

s negativním dopadem na KV prognózu nemocných. Navíc díky zlepšené péči se více nemocných s diabetem 1. typu dožívá vyššího věku, kdy stoupá i význam ASKVO.

\section{Pacienti po akutním koronárním syndromu (AKS) a podstupující perkutánní koronární revaskularizaci}

Nemocní po akutním koronárním syndromu jsou ohroženi jeho recidivou a mají velmi vysoké riziko aterotrombotické komplikace i v jiném povodí. Proto zasluhují maximální pozornost a intenzitu léčby dyslipidemie. Zásadní principy přístupu $\mathrm{k}$ pacientům se nezměnily, a proto můžeme nadále odkazovat na dokument ČSAT ve spolupráci s Pracovní skupinou akutní a intervenční kardiologie České kardiologické společnosti (ČKS) z roku 2012. ${ }^{9}$ Nově celkový prístup $\mathrm{k}$ nemocným po prodělané akutní koronární příhodè shrnuje dokument vypracovaný skupinou expertů zastupujících české odborné společnosti. ${ }^{10}$

Skupina nemocných s anamnézou AKS byla v poslední době intenzivně zkoumána a data získaná ve studiích zařazujících tyto pacienty umožnila lepší pochopení významu rychlého a intenzivního snižování aterogenních lipoproteinů po AKS. Poslední takovou práci představuje studie EVOPACS s evolocumabem nasazovaným u pacien-
Tabulka 11 - Doporučení pro hypolipidemickou léčbu u pacientů s velmi vysokým rizikem a akutními koronárními syndromy

Doporučení

Trída

Úroveň

U všech nemocných s AKS je nezávisle na vstupních hodnotách LDL-C doporučeno brzy po prijetí zahájit léčbu vysokými dávkami statinu nebo v ní dále pokračovat, pokud nejsou kontraindikace nebo anamnéza intolerance.

Koncentrace lipidů by měly být vyšetřeny znovu za čtyři až šest týdnů po AKS k ověrení, zda bylo dosaženo cílových hodnot $\mathrm{LDL}-\mathrm{C}<1,4 \mathrm{mmol} / \mathrm{l}$ a současně snížení alespoň o $50 \%$ a zda se neobjevily nežádoucí účinky. Dávka hypolipidemik by měla být upravena dle výsledku.

Pokud není dosaženo maximálními tolerovatelnými dávkami statinu během čtyř až šesti týdnů cílových hodnot LDL-C, je indikována kombinace $s$ ezetimibem.

Pokud není dosaženo maximálními tolerovatelnými dávkami statinu $v$ kombinaci s ezetimibem během čtyř až šesti týdnů cílových hodnot LDL-C, je doporučeno zahájit léčbu inhibitory PCSK9

U pacientů s prokázanou statinovou intolerancí nebo kontraindikací statinů by měla být zvážena terapie ezetimibem.

U pacientů, u nichž není dosaženo kontroly LDL-C maximální tolerovanou dávkou statinu a ezetimibem a vznikne u nich AKS, má být zvážena časná indikace inhibitoru PCSK9, je-li to možné, ještě za hospitalizace.

U pacientů podstupujících elektivní $\mathrm{PCl}$ nebo PCI v kontextu AKS by mělo být zváženo podání vysoké dávky statinu.

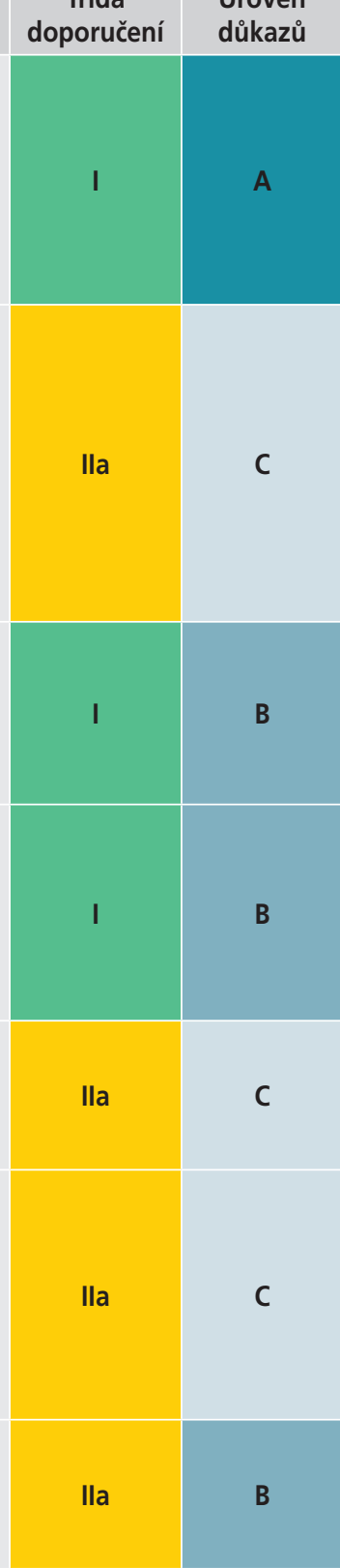

AKS - akutní koronární syndrom; LDL-C - LDL-cholesterol; PCI perkutánní koronární intervence; PCSK9 - inhibitory proprotein konvertázy subtilisin/kexin typu 9.

tů do $72 \mathrm{~h}$ po AKS za hospitalizace (téměř dvě třetiny ze zařazených dostali studijní léčbu do $24 \mathrm{~h}$ od prezentace AKS). Dle očekávání byly splněny primární lipidové sledované cíle (významně výraznější pokles LDL-C ve větvi statin + evolocumab ve srovnání s větví statin + placebo) Zajímavější data můžeme očekávat od zobrazovacích podstudií dokumentovaných pokročilými zobrazovacími metodami, které by měly ukázat, jaký vliv na složení aterosklerotických lézí akutní výrazné snižení koncentrací aterogenních lipoproteinů má (tabulka 11). ${ }^{11}$ 
Tabulka 12 - Doporučení pro hypolipidemickou terapii u pacientů po prodělané ischemické cévní mozkové př̌hodě

\begin{tabular}{l|c|c|}
\hline Doporučení & $\begin{array}{c}\text { Třída } \\
\text { doporučení }\end{array}$ & $\begin{array}{c}\text { Úroveň } \\
\text { důkazů }\end{array}$ \\
\hline $\begin{array}{l}\text { Pacienti s anamnézou ischemické } \\
\text { cévní mozkové příhody nebo } \\
\text { tranzitorní ischemické ataky } \\
\text { mají velmi vysoké riziko ASKVO } \\
\text { (zejména rekurentní CMP), }\end{array}$ & \\
$\begin{array}{l}\text { a proto je doporučena intenzivní } \\
\text { hypolipidemická terapie ke snížení } \\
\text { LDL-C. }\end{array}$ & \\
\end{tabular}

ASKVO - aterosklerotické kardiovaskulární onemocnění; CMP cévní mozková příhoda; LDL-C - LDL-cholesterol.

\section{Pacienti s anamnézou ischemické cévní mozkové příhody}

Doporučení ESC/EAS 2019 pro léčbu dyslipidemií se poprvé v samostatném odstavci vyjadřují k oblasti hypolipidemické intervence $u$ nemocných $s$ anamnézou ischemické cévní mozkové příhody (CMP). Připomínají, že ischemická CMP má různé příčiny, z nichž řada nesouvisí s aterotrombózou. Na druhou stranu pacienti s anamnézou ischemické CMP mají obecně velmi vysoké riziko aterotrombotické příhody - at' už v podobě rekurentní cerebrovaskulární př́ihody, nebo postižení jiného povodí. Guidelines rovněž konstatují možnost mírného navýšení rizika hemoragické CMP u uživatelů statinů. V této souvislosti dodejme, že toto riziko je malé a vyvažuje jej přínos v podobě snížení výskytu ischemických příhod. Navíc evidence dokládající souvislost s terapií statiny a krvácivou CMP není jednoznačná (tabulka 12).

\section{Pacienti se srdečním selháním a chlopenními vadami}

Neutrální výsledky klinických studií se statiny u pacientů se srdečním selháním či aortální stenózou vedly k doporučení nezahajovat farmakoterapii hypolipidemiky u těchto pacientů. Připomeňme však, že léčba statiny je u těchto skupin nemocných bezpečná, a existuje-li nějaká další indikace pro jejich podání, má být léčba vedena se stejnými principy jako u ostatních osob.

\begin{tabular}{|c|c|c|}
\hline Doporučení & $\begin{array}{c}\text { Trída } \\
\text { důkazů }\end{array}$ & $\begin{array}{l}\text { Úroveň } \\
\text { doporučení }\end{array}$ \\
\hline $\begin{array}{l}\text { U nemocných se srdečním selháním } \\
\text { není zahájení léčby statiny } \\
\text { doporučeno, pokud pro ni není jiná } \\
\text { indikace. }\end{array}$ & III & A \\
\hline $\begin{array}{l}\text { Hypolipidemická léčba není } \\
\text { doporučena u pacientů s aortální } \\
\text { stenózou bez anamnézy ASKVO, } \\
\text { pokud není pro tuto léčbu jiná } \\
\text { indikace }\end{array}$ & III & A \\
\hline
\end{tabular}

ASKVO - aterosklerotické kardiovaskulární onemocnění.
Ani nové studie s inhibitory PCSK9 nepřinesly nové informace. $V$ některých $z$ nich se sice ukázala možnost asociace mezi osou receptor PCSK9-LDL a výskytem aterotrombotických příhod u pacientů se srdečním selháním, ale vliv na průběh srdečního selhání zjištěn nebyl. I u inhibitorů PCSK9 tedy platí, že nejsou indikovány z důvodu ovlivnění průběhu srdečního selhání.

Malý prínos podávání $\omega-3$ mastných kyselin v kontextu srdečního selhání nebyl v poslední době dále rozpracován, a proto tuto možnost nová doporučení z tabelárního přehledu (tabulka 13) vypouštějí.

\section{Pacienti s autoimunitními chorobami}

Autoimunitní onemocnění (revmatoidní artritida, systémový lupus erythematodes, psoriáza) zejména s vystupňovanou zánětlivou aktivitou nepochybně zvyšují kardiovaskulární riziko. Heterogenita pacientských populací a absence velkých klinických studií v této oblasti nedovolují formulovat specifická doporučení. Hypolipidemická farmakoterapie má být indikována u těchto pacientů podle jejich aktuálního KV rizika. Samotná př́tomnost chronického autoimunitního onemocnění není indikací pro podání hypolipidemik. V tomto oddíle se doporučení nemění proti verzi z roku 2016.

\section{Pacienti s chronickým onemocněním ledvin}

Chronické renální postižení zvyšuje kardiovaskulární riziko a může alterovat metabolismus lipidů v séru. Intenzivní pátrání po prítomnosti renálního onemocnění je podmínkou správného stanovení KV rizika i volby léčebné strategie. Pacienti se středně závažným až závažným poklesem renálních funkcí jsou klasifikováni jako vysoce nebo velmi vysoce cévně rizikoví a intervence DLP u nich musí být vedena k dosažení cílových hodnot LDL-cholesterolu (ev. non-HDL-cholesterolu) (tabulka 14).

Tabulka 14 - Doporučení pro léčbu dyslipidemií u pacientů se středně těžkým nebo těžkým postižením renálních funkcí

\begin{tabular}{l|c|c}
\hline Doporučení & $\begin{array}{c}\text { Trída } \\
\text { doporučení }\end{array}$ & $\begin{array}{c}\text { Úroveň } \\
\text { důkazů }\end{array}$ \\
\hline $\begin{array}{l}\text { Pacienti s CKD stadia } 3 \text { musejí být } \\
\text { posuzováni jako nemocní s vysokým } \\
\text { a nemocní s CKD 4.-5. stadia s velmi } \\
\text { vysokým rizikem ASKVO. }\end{array}$ & I & A \\
\hline $\begin{array}{l}\text { Léčba statiny nebo kombinací statin/ } \\
\text { ezetimib je indikována u těch } \\
\text { nemocných s CKD, kteří nejsou } \\
\text { zařazeni v dialyzačním programu. }\end{array}$ & I & A \\
\hline $\begin{array}{l}\text { U dialyzovaných pacientů bez } \\
\text { ASKVO by léčba statiny neměla být } \\
\text { zahajována. }\end{array}$ & III & A \\
\hline $\begin{array}{l}\text { U nemocných léčených statiny nebo } \\
\text { kombinací statin/ezetimib již před } \\
\text { zařazením do dialýzy by se mělo } \\
\text { v léčbě pokračovat, zejména pokud } \\
\text { tito nemocní mají anamnézu ASKVO. }\end{array}$ & Ila & A \\
\hline
\end{tabular}

ASKVO - aterosklerotické kardiovaskulární onemocnění; CKD chronické onemocnění ledvin. 
Tabulka 15 - Doporučení pro léčbu dyslipidemií u nemocných po transplantacich

Doporučení

U pacientů po transplantacích by měl být jako lék první volby zvážen statin. Léčbu je třeba zahájit nízkými dávkami a poté opatrně titrovat. Pozornost je třeba věnovat lékovým interakcím, zejména s cyklosporinem.

U pacientů, kteři netolerují statiny, nebo mají stále významnou dyslipidemii a vysoké reziduální riziko i při maximální tolerované dávce statinu, Ize zvážit alternativní nebo kombinovanou léčbu s ezetimibem.

ASKVO - aterosklerotické kardiovaskulární onemocnění.

\section{Pacienti po orgánové transplantaci}

Nemocní po transplantačních výkonech mají zvýšené riziko ASKVO v důsledku primárního onemocnění i nezbytné léčby po transplantaci. Nutnost imunosupresivní a další konkomitantní medikace činí vedení léčby DLP obtížnější; sama tato léčba může alterovat metabolismus lipoproteinů v séru. Přesto by měla být vyvíjena maximální snaha o dosažení uspokojivé kontroly lipidogramu s využitím hypolipidemické terapie (tabulka 15).

\section{Pacienti s nekoronární aterosklerózou (aterosklerotickým postižením periferních tepen)}

Nemocní s aterosklerotickým postižením periferních tepen (karotid, abdominální aorty, končetinových tepen, renálních tepen) mají velmi vysoké $\mathrm{KV}$ riziko, a proto léčba dyslipidemie u těchto pacientů musí být maximálně intenzivní. Po postižení periferních tepen je třeba pátrat $\mathrm{u}$ všech pacientů s velmi vysokým rizikem. Principy hypolipidemické intervence se neliší od ostatních skupin v této kategorii rizika, stejné jsou i léčebné cíle. Nově doporučení výslovně uvádějí, že terapie u nemocných s nekoronární aterosklerózou má být vedena maximální tolerovanou dávkou statinu s ezetimibem a prípadně s inhibitorem PCSK9 tak, aby bylo dosaženo cílové hodnoty LDL-C.

\section{Pacienti s pozitivitou HIV}

Intervence dyslipidemie poutá v poslední době u HIV pozitivních pacientů stále více pozornosti. Dưvodů je několik. Díky moderní léčbě HIV pozitivní pacienti přežívají podstatně déle, a tak se u nich setkáváme častěji s KV komplikacemi. Navíc protiinfekční léčba přináší řadu metabolických nežádoucích účinků (např. inzulinovou rezistenci). Hypolipidemická léčba má poměrně vysoké riziko nežádoucích lékových interakcí s antiretrovirovými léčivy (inhibitory proteáz). Doporučení uvádějí, že preferovanými statiny by měly být pravastatin, fluvastatin, pitavastatin a rosuvastatin (simvastatin a lovastatin mají s inhibitory proteáz silnou interakci) léčba má být vedena za předpokladu pečlivé monitorace pacienta.
Tabulka 16 - Doporučení pro léčbu hypolipidemiky u pacientů s psychiatrickými onemocněními

\begin{tabular}{l|c|c|}
\hline Doporučení & $\begin{array}{c}\text { Trída } \\
\text { doporučení }\end{array}$ & $\begin{array}{c}\text { Úroveň } \\
\text { důkazů }\end{array}$ \\
\hline $\begin{array}{l}\text { Těžká psychiatrická onemocnění } \\
\text { modifikují celkové riziko ASKVO. }\end{array}$ & I \\
\hline $\begin{array}{l}\text { Postup ovlivnění kardiovaskulárního } \\
\text { rizika u nemocných s psychiatrickými } \\
\text { onemocněními se neliší od postupu } \\
\text { u pacientů s vysokým a velmi }\end{array}$ & I & C \\
$\begin{array}{l}\text { vysokým rizikem ASKVO. } \\
\begin{array}{l}\text { U pacientů s psychiatrickými } \\
\text { onemocněními je třeba věnovat } \\
\text { pozornost zejména adherenci } \\
\text { k úpravám životního stylu } \\
\text { a farmakologické léčbě. }\end{array}\end{array}$ & \\
\hline
\end{tabular}

ASKVO - aterosklerotické kardiovaskulární onemocnění.

\section{Pacienti s psychiatrickými onemocněními}

Ve výčtu specifických pacientských skupin najdeme dále také pacienty s psychiatrickými onemocněními. Guidelines si všímají několika důležitých aspektů: KV riziko těchto pacientů je často zvýšeno v důsledku vysoké prevalence rizikových faktorů (zejména kouření či abúzu dalších návykových látek, nízké pohybové aktivity, nevhodné diety apod.), zvýšené míry stresu, metabolických nežádoucích účinků psychofarmakoterapie a v neposlední řadě v důsledku non-adherence $\mathrm{k}$ doporučením. $\mathrm{V}$ důsledku toho se ASKVO vyskytují u pacientů s psychiatrickou diagnózou přibližně o deset let dříve než v běžné populaci. I proto je management rizikových faktorů včetně hypolipidemické farmakoterapie u těchto pacientů indikován (tabulka 16).

\section{Laboratorní monitorování pacientů léčených hypolipidemiky}

Podobně jako v předchozích verzích doporučených postupů i nyní musíme předeslat, že doporučení pro monitoring pacientů během hypolipidemické léčby vychází z konsenzu expertů, nebot' nemáme $\mathrm{k}$ dispozici studie, které by posuzovaly různé vhodné strategie monitorace pacientů. Na druhé straně, tato sekce doporučení nedoznala podstatných změn a vychází z postupů osvědčených klinickou praxí. Na tomto místě je třeba připomenout, že přes nutnou individualizaci sledování pacientů se zohledněním jejich charakteristik (komorbidity, konkomitantní medikace, výskyt nežádoucích účinků apod.) se v praxi setkáváme spíše $s$ vyšší četností kontrol a širším panelem rutinně testované „bezpečnostní" laboratoře. Připomeňme, že statiny (ale i ezetimib či inhibitory PCSK9) mají mimořádně příznivý bezpečnostní profil a stabilizované pacienty můžeme testovat ne častěji než jednou ročně.

Při nálezu zvýšené hodnoty kreatinkinázy (CK) a/nebo při výskytu myalgií je doporučeno vždy aktivně pátrat po jiné etiologii těchto symptomů. Izolovaný vzestup CK bez myalgií většinou nemívá kauzální souvislost se statiny, častými př́činami bývá např. zvýšená svalová námaha, svalové poranění (včetně např. i.m. injekce), alkohol, virové a bakteriální infekty, endokrinopatie, chronické srdeč- 
Tabulka 17 - Doporučení pro monitoraci koncentrací lipidů a enzymů při léčbě hypolipidemiky

\section{Monitorace koncentrací lipidů}

Jak často vyšetřovat koncentrace lipidů?

- Před zahájením hypolipidemické léčby provést alespoň dvě měření v intervalu 1-12 týdnů, s výjimkou stavů, kdy je doporučeno okamžité zahájení léčby (AKS a pacienti s velmi vysokým rizikem).

Jak často vyšetřovat lipidy po zahájení léčby hypolipidemiky?

- 8 ( \pm 4$)$ týdny po zahájení léčby.

- 8 ( \pm 4 ) týdny po úpravě dávkování až do dosažení cílových hodnot.

Jak často vyšetřovat lipidy po dosažení cílových nebo optimálních hodnot?

- Jednou ročně (pokud nejsou problémy s adherencí k léčbě nebo jiné důvody pro častější kontroly).

Monitorace jaterních a svalových enzymů

Jak často rutinně vyšetřovat jaterní testy (ALT) u pacientů užívajících hypolipidemika?

- Před léčbou.

- Jednou za 8-12 týdnů po zahájení léčby nebo zvýšení dávky.

- Poté již rutinní vyšetřování ALT není během hypolipidemické léčby doporučeno.

- Při léčbě fibráty se doporučuje koncentrace ALT sledovat.

Co dělat, když se zvýší jaterní testy u pacienta užívajícího hypolipidemika?

$K d y z ̌$ je $A L T<3 \times$ ULN:

- Pokračovat v léčbě.

- Zkontrolovat jaterní testy za čtyři až šest týdnů.

Když je $A L T \geq 3 \times$ ULN:

- Vysadit hypolipidemika nebo snižit jejich dávku a znovu zkontrolovat jaterní testy za čtyři až šest týdnů.

- Opatrné opětovné nasazení hypolipidemika Ize zvážit po normalizaci ALT.

- Pokud přetrvává zvýšení ALT, je třeba vyloučit jiné možné příčiny.

Jak často vyšetřovat CK u pacientů užívajících hypolipidemika?

Před léčbou:

- Před zahájením léčby.

- Pokud je vstupní CK $\geq 4 \times$ ULN, nezahajovat léčbu a znovu zkontrolovat.

Monitorace:

- Rutinní monitorování CK není třeba

- Vyšetřit CK, pokud se objeví svalové bolesti.

- Myslet na možnost myopatie a zvýšení CK u rizikových nemocných, jako jsou: senioři, pacienti se současnou léčbou vedoucí k lékovým interakcím, pacienti užívající více léků, pacienti s jaterním nebo renálním onemocněním nebo sportovci.

Co dělat, když se zvýší CK u pacienta užívajícího hypolipidemika?

$K d y z ̌$ je $C K \geq 4 \times$ ULN:

- Pokud je CK > 10x ULN, je třeba přerušit léčbu, zkontrolovat renální funkce a monitorovat koncentraci CK každé dva týdny.

- Pokud je CK < 10x ULN a nemocný je asymptomatický, je možno pokračovat v podávání hypolipidemik při monitoraci koncentrací CK à dva až šest týdnů.

- Pokud je CK < 10x ULN a nemocný má obtíže, je třeba přerušit léčbu a monitorovat CK do její normalizace. Po normalizaci CK je možno zkusit nasadit nižší dávku statinu.

- Zvážit možnost přechodného zvýšení CK z jiných důvodů jako např. cvičení.

- Zvážit možnost myopatie, pokud přetrvává elevace CK.

- Zvážit podávání kombinované léčby nebo jiného léku po poklesu CK.

Když je CK < 4x ULN:

- Pokud nejsou svalové obtíže, pokračovat v léčbě statinem (nemocný by měl být poučen, aby ihned oznámil příp. obtíže; je třeba zkontrolovat CK).

- Pokud jsou svalové bolesti, monitorovat pravidelně př́znaky a hodnoty CK.

- Pokud přetrvávají myalgie, přerušit léčbu statinem a obtíže znovu zhodnotit za šest týdnů. Znovu přehodnotit indikaci k léčbě statinem.

- Zvážit znovunasazení stejného nebo jiného statinu.

- Zvážit podávání nižší dávky statinu nebo podávání obden nebo jednou/dvakrát týdně nebo podávání kombinované léčby.

U kterých pacientů testovat $\mathrm{HbA}_{1 \mathrm{c}}$ nebo glykemii nalačno?

- Pravidelné kontroly $\mathrm{HbA}_{1 c}$ by měly být zváženy u osob s vysokým rizikem rozvoje diabetu užívajících vysoce intenzivní terapii statinem.

- Monitorace lačné glykemie má být zvážena u starších osob, pacientů s metabolickým syndromem, obezitou a dalšími známkami inzulinové rezistence.

AKS - akutní koronární syndrom; ALT - alaninaminotransferáza; CK - kreatinkináza; $\mathrm{HbA}_{1 c}$ - glykovaný hemoglobin; ULN - horní limit referenčního rozmezí. 
ní onemocnění, přidání jiné medikace (např. kortikoidy, antibiotika, antipsychotika, imunosupresiva a řada dalších). U některých osob může být asymptomatická trvalá (a kolísající) elevace CK bez zjistitelné příčiny. Některé $z$ výše uvedených příčin mohou vést také $k$ myalgiím (virové infekty, alkohol, svalová námaha a další) (tabulka 17).

\section{Nákladová efektivita prevence kardiovaskulárních príhod intervencí dyslipidemie}

V poslední době se do klinického použití dostávají hypolipidemické intervence spojené s vysokými náklady na léčbu (např. inhibitory PCSK9, lomitapid, anti-sense terapie). Proto se i verze doporučených postupů $\mathrm{k}$ managementu dyslipidemií 2019 k této otázce vyjadřuje ve zvláštním a nově zařazeném oddíle. $Z$ originálního textu vybíráme tabulku shrnující klíčová fakta k tématu (tabulka 18).

Tabulka 18 - Kličová fakta k nákladové efektivitě prevence KVO hypolipidemickou intervencí

Prevence KVO změnami životního stylu, léky nebo obojím je nákladově efektivní v mnoha scénáríích, včetně populačních přistupů a akcí zaměřených na osoby se zvýšeným rizikem KVO.

Nákladová efektivita závisí na několika faktorech, včetně rizika KVO před léčbou a koncentracích LDL-C, nákladech na léčbu a využívání preventivních strategií.

Intervence posilující prevenci KVO jsou nákladově efektivnější u jednotlivců a populací s vyšším rizikem KVO.

Pro analýzy nákladové efektivity jsou důležité informace o dlouhodobé prognóze onemocnění a účincích léčby. Posílení důkazů ke zpřesnění takových údajů se doporučuje.

KVO - kardiovaskulární onemocnění; LD-C - LDL-cholesterol.

Přestože tematika nákladové efektivity je velmi důležitá, připomeňme, že zhodnocení tohoto parametru vyžaduje (často chybějící) vstupní informace o dlouhodobé prognóze onemocnění v různých stadiích vývoje a také data o dlouhodobém efektu terapií. Modelování používané pro analýzy nákladové efektivity je náročné a často se dynamicky mění v souvislosti se změnami cen i dalších údajů tvořících vstupy takových analýz. Zásadně nelze přenášet výsledky nákladových analýz z prostředí jednoho zdravotního systému do jiného; vždy musíme pracovat s regionálně specifickými daty.

\section{Adherence $\mathrm{k}$ režimovým i farmakoterapeutickým postupům}

V poslední kapitole doporučení pro léčbu dyslipidemií ESC/EAS 2019 najedeme stat' věnovanou adherenci. $S$ ohledem na fakt, že hypolipidemické intervence patří mezi preventivní strategie, jejichž efekt Ize hodnotit s odstupem (někdy i desítek) let, představuje adherence v této oblasti jeden ze zásadních faktorů, jimž je třeba věnovat pozornost v každodenní praxi. Tabulka 19 shrnuje nejdůležitější body týkající se adherence.
Tabulka 19 - Nejdůležitější pravidla pro zvýšení adherence

1. Prozkoumejte motivaci a identifikujte ambivalenci. Zvažte klady a zápory, změny, posud'te a posilujte soběstačnost a sebedůvěru; vyhněte se kruhovým diskusím.

2. Nabídněte podporu a navažte vztah s pacientem a jeho/její rodinou.

3. Zapojte partnera, ostatní členy domácnosti nebo pečovatele, kteří mohou ovlivňovat životní styl pacienta.

4. Použijte metodu OARS (otevřené otázky, potvrzení, reflektivní poslech, shrnutí při diskusi o změnách chování) (www.smartrecovery.org/wp-content/uploads/2017/03/ UsingMlinSR.pdf).

5. Přizpůsobte rady individuální kultuře pacienta, jeho zvyklostem a situaci.

6. Použijte nastavení cílů metodou SMART (vyjednat cíle změn, které jsou specifické, měřitelné, dosažitelné, realistické a termínované). Sledujte dosahování cílů a zaznamenejte pokrok na sdíleném záznamu.

Je jisté, že dưraz na dosažení dobré a dlouhodobé adherence nemocných k léčebným opatřením zásadním způsobem ovlivňuje efektivitu léčby i prognózu nemocných.

\section{Shrnutí hlavních myšlenek doporučení pro} léčbu DLP ESC/EAS verze 2019

1. Cholesterol a riziko. Prospektivní studie, randomizované studie a mendeliánské randomizované studie ukázaly, že vysoká koncentrace LDL-C je příčinou ASKVO. V celém rozsahu koncentrací LDL-C platí princip „čím níže, tím lépe”, přinejmenším do úrovně $1 \mathrm{mmol} / \mathrm{l}$. Snížení rizika ASKVO dosažitelné redukcí LDL-C (např. statinem, ezetimibem nebo inhibitorem PCSK9) závisí na absolutním snížení LDL-C, přičemž každá redukce o $1 \mathrm{mmol} / \mathrm{l}$ odpovídá poklesu rizika ASKVO asi o jednu pětinu.

2. Inhibitory PCSK9. Velké studie ukázaly, že inhibitory PCSK9 dále snižují riziko ASKVO, pokud jsou přidávány k terapii založené na statinu. Jejich použití zatím zůstává omezeno na ty v nejvyšším riziku ASKVO.

3. Použití zobrazovacích metod pro stratifikaci rizika. Stanovení kalciového skóre koronárních tepen (skóre $(A C)$ pomocí $C T$ může být užitečné při rozhodování o léčbě u nemocných ve středním riziku ASKVO. Výsledek skóre CAC mưže být užitečný při diskusi s pacientem, který nedosahuje cílové hodnoty LDL-C při režimových opatřeních a je zvažována farmakologická léčba. Podobně Ize využít dokumentaci jednoznačného aterosklerotického plátu při ultrazvukovém vyšetření karotid nebo femorálních tepen.

4. Použití apolipoproteinu B při stratifikaci rizika. Apolipoprotein B může být lepším ukazatelem expozice jednotlivce aterogenním lipoproteinům, a proto může být jeho použití zvláště užitečné při posuzování rizika u osob, kde měření LDL-C vede $k$ podcenění tohoto rizika (osoby s vysokými hodnotami TG, DM, obezitou nebo velmi nízkou koncentrací LDL-C).

5. Použití lipoproteinu(a) při stratifikaci rizika. Jednorázové stanovení Lp(a) může pomoci identifikovat osoby s velmi vysokou koncentrací $L p(a)$, které 
mohou mít značné celoživotní riziko ASKVO. Může být také nápomocný při další stratifikaci rizika u pacientů s vysokým rizikem ASKVO, u pacientů s předčasnou manifestací ASKVO v rodinné anamnéze a napomoci určit léčebné strategie u osob, u nichž se odhad rizika pohybuje na rozhraní rizikových kategorií.

6. Zpřísnění léčebných cílů. Základním požadavkem u pacientů s nejvyšším rizikem zůstává co největší možné snížení LDL-C. Cílem těchto doporučení je podpořit tento požadavek nastavením minimálního procentního snížení LDL-C (50 \%) a současně absolutního cíle léčby $L D L-C<1,4 \mathrm{mmol} u$ velmi vysoce rizikových a $\mathrm{LDL}-\mathrm{C}<1,8 \mathrm{mmol} / \mathrm{l}$ u vysoce rizikových pacientů. Je doporučeno, aby pacienti s familiární hypercholesterolemií a manifestním ASKVO nebo aspoň jedním dalším rizikovým faktorem byli léčeni jako velmi vysoce rizikoví a ostatní nemocní s FH jako vysoce rizikoví.

7. Léčba pacientů po prodělaném AKS. Nové randomizované klinické studie podporují strategii intenzifikace terapie snižující LDL-C u velmi vysoce rizikových pacientů s AKS (akutní infarkt myokardu nebo nestabilní angina pectoris). Není-li dosaženo cílové hodnoty LDL-C po čtyřech až šesti týdnech léčby nejvyšší tolerovanou dávkou statinu a ezetimibem, je vhodné přidat inhibitor PCSK9.

8. Bezpečnost nízkých koncentrací LDL-cholesterolu. Nejsou známy žádné nepříznivé účinky velmi nízkých koncentrací LDL-C (např. < $1 \mathrm{mmol} / 1$ ).

9. Management statinové „intolerance“. Zatímco statiny zřídka způsobí vážné poškození svalů (myopatie nebo rhabdomyolýza), veřejnost (laickou i odbornou) znepokojuje, že statiny mohou zpưsobit méně závažné svalové př́znaky. S touto statinovou intolerancí a pseudointolerancí (symptomy s léčbou statiny nemají vůbec příčinnou souvislost) se setká řada lékařư v terénu a je obtížně řešitelná. Randomizované studie srovnávající statin zaslepeně s placebem velmi přesvědčivě ukázaly, že skutečná nesnášenlivost statinů je vzácná a že většinou je možné nějakou formu terapie statiny podávat (např. jiný statin, upravená dávka, alternativní dávkování).

10. Léčba statiny u osob vyššího věku. Metaanalýzy randomizovaných studií ukázaly, že účinky léčby statiny jsou determinovány absolutní dosaženou redukcí LDL-C a mírou rizika ASKVO před zahájením léčby. Důležité je, že tyto účinky jsou nezávislé na ostatních rizikových faktorech včetně věku. Z toho vyplývá, že terapie statiny u seniorů má vycházet ze stejných principů a být vedena stejně jako u mladších. Zvláštní pozornost vyžaduje zhodnocení celkového zdravotního stavu a možných lékových interakcí. Méně dat máme pro léčbu statiny u osob starších 75 let, zejména v primární prevenci. U populace seniorů se obecně doporučuje zahajování terapie nižšími dávkami a jejich titrací k dosažení cílových hodnot LDL-C.

\section{Literatura}

1. Mach F, Baigent C, Catapano AL, et al. ESC Scientific Document Group. 2019 ESC/EAS Guidelines for the management of dyslipidaemias: lipid modification to reduce cardiovascular risk. Eur Heart J 2020;41:111-188.

2. Catapano AL, Graham I, De Backer J, et al. 2016 ESC/EAS Guidelines for the Management of Dyslipidaemias. Eur Heart J 2016;37:2999-3058.

3. Vrablík M, Pitha J, Blaha V, et al. Stanovisko výboru ČSAT $k$ doporučením ESC/EAS pro diagnostiku a léčbu dyslipidemií z roku 2016. AtheroRev 2017;2:185-193.

4. Soška V, Franeková J, Friedecký B, et al. Společné stanovisko českých odborných společností ke konsenzu European Atherosclerosis Society a European Federation of Clinical Chemistry and Laboratory Medicine k vyšetřování krevních lipidů a k interpretaci jejich hodnot. AtheroRev 2017;2:33-39.

5. Češka $R$, Táborský $M$, Vrablík M. Společné stanovisko odborných společností k předepisování PCSK9 inhibitorů. Vnitř Lék 2018;64:1131-1136.

6. Soška V, Vrablík M, Blaha V, et al. Indikace PCSK9 inhibitorů v nové léčbě hypercholesterolemie v zorném poli ČSAT. Hypertenze a KV prevence 2016;1:33-35.

7. Vrablík M, Češka R, Blaha V, et al. Souhrn konsenzu panelu expertů European Atherosclerosis Society k otázce diagnostiky a klinickému vedení nemocných s homozygotní formou familiární hypercholesterolemie. Hypertenze a KV prevence 2015;2:59-61.

8. Urbanová Z, Freiberger T, Šamánek M, et al. Komentář k souhrnu konsenzu panelu expertů European Atheroslerotic Society k otázce optimalizace diagnostiky a léčby dětí s familiární hypercholesterolemií. Hypertenze a KV prevence 2016;1:36-38.

9. Pitha J, Štulc T, Janota T, et al. Léčba statiny u pacientů s akutním koronárním syndromem. Interv Akut Kardiol 2012;11:89-90.

10. Oštádal $P$, Táborský $M$, Linhart $A$, et al. Stručný souhrn doporučení pro dlouhodobou péči o nemocné po infarktu myokardu. Cor Vasa 2019;61:471-480.

11. Koskinas KC, Windecker S, Pedrazzini G et al. Evolocumab for Early Reduction of LDL-Cholesterol Levels in Patients with Acute Coronary Syndromes (EVOPACS). J Am Coll Cardiol 2019; pii: S07351097(19)36274-6.

12. Baigent C, Blackwell L, Emberson J, et al. [Cholesterol Treatment Trialists' (CTT) Collaboration]. Efficacy and safety of more intensive lowering of LDL cholesterol: a meta-analysis of data from 170,000 participants in 26 randomised trials. Lancet 2010;376:1670-1681.

13. Cannon CP, Blazing MA, Giugliano RP, et al. [IMPROVEIT Investigators]. Ezetimibe Added to Statin Therapy after Acute Coronary Syndromes. N Engl J Med 2015;372:2387-2397.

14. Sabatine MS, Giugliano RP, Keech AC, et al. [FOURIER Steering Committee and Investigators]. Evolocumab and Clinical Outcomes in Patients with Cardiovascular Disease. N Engl J Med 2017;376:1713-1722.

15. Schwartz GG, Steg PG, Szarek M et al. [ODYSSEY OUTCOMES Committees and Investigators]. Alirocumab and Cardiovascular Outcomes after Acute Coronary Syndrome. N Engl J Med 2018;379:2097-2107.

Článek byl publikován v časopise AtheroRev 2019;4:126-137 a upraven. 